\title{
PENENTUAN INDEKS BAHAYA KEKERINGAN AGRO-HIDROLOGI: STUDI KASUS WILAYAH SUNGAI KARIANGO SULAWESI SELATAN
}

\section{Determination of Agro-Hidrology Drought Hazard Index: A Case Study of Kariango River Area at South Sulawesi}

\author{
Muhammad Munawir Syarif1)*, Baba Barus's), dan Sobri Effendy3) \\ 1)Alumni Program Studi Mitigasi Bencana Kerusakan Lahan, Departemen Ilmu Tanah Dan Sumberdaya Lahan, \\ Fakultas Pertanian IPB, J1. Meranti Kampus IPB Darmaga, Bogor 16680 \\ 2) Departemen Ilmu Tanah dan Sumberdaya Lahan, Fakultas Pertanian IPB, J1. Meranti Kampus IPB Darmaga \\ Bogor 16680 \\ 3)Departemen Geofisika dan Meteorologi, Fakultas Matematika dan Ilmu Pengetahuan Alam IPB, Jl. Meranti
} Kampus IPB Darmaga Bogor 16680

\begin{abstract}
Agro-hydrological drought can be interpreted as a shortage of surface water and ground water supplying and insufficient for plants and society needs for a certain period. So far there have been no agro-hidrology drought index that combine climate, surface and ground factors. This study develops a Drought Hazard Index (DHI) as an indicator of AgroHydrological drought. The model developed from a combination of dry season rainfall, ground water depth, distance of water sources, soil texture and Water Supply Vegetation Index (WSVI) using remote sensing and GIS methods. The Agro-hidrology Drought Hazard Index developed is DHI $=(0.33 \mathrm{CH})+(0.27 \mathrm{KAT})+(0.20 \mathrm{SA})+(0.13 \mathrm{~T})+(0.06$ WSVI) with model validation results showed high similarity drought in the field.
\end{abstract}

Keywords: Agro-hidrology drought, GIS analysis, hazard index, remote sensing

\begin{abstract}
ABSTRAK
Kekeringan agro-hidrologi dapat diartikan sebagai kekurangan air permukaan, air tanah dan mencukupi untuk tanaman dan kebutuhan masyarakat untuk jangka waktu tertentu. Sejauh ini belum ada indeks kekerigan agro-hidrologi yang menggabungkan faktor iklim, air permukaan, dan air bawah permukaan tanah. Penelitian ini merumuskan sebuah indeks bahaya kekeringan (Ibk) sebagai indikator kekeringan agro-hidrologi. Model yang dikembangkan dari kombinasi curah hujan musim kering, kedalaman air tanah, jarak sumber air, tekstur tanah dan indeks ketersediaan air bagi tanaman dengan menggunakan metode penginderaan jauh dan GIS. Indeks bahaya kekeringan agro-hidrologi yang telah dikembangkan adalah $\mathrm{Ibk}=(0.33 \mathrm{CH})+(0.27 \mathrm{KAT})+(0.20 \mathrm{SA})+(0.13 \mathrm{~T})+(0.0 \mathrm{WSVI})$ dengan hasil validasi model menunjukkan kemiripan yang tinggi kekeringan di lapangan.
\end{abstract}

Kata kunci: Kekeringan agro-hidrologi, analisis GIS, indeks bahaya, penginderaan jauh

\section{PENDAHULUAN}

Kekeringan didefinisikan secara umum adalah kurangnya ketersediaan air untuk sementara/dalam jangka waktu tertentu. Kekeringan dapat diartikan juga sebagai suatu keadaan dimana terjadi kekurangan air, dalam hal ini biasanya dikonotasikan dengan kekurangan air hujan (Raharjo, 2010). Bencana kekeringan merupakan bencana yang terjadi secara perlahan akan tetapi dapat menimbulkan kerusakan dan kerugian yang sangat besar. Beberapa dari dampak kekeringan adalah krisis air dan krisis pangan.

Krisis pangan dapat terjadi di Indonesia, yang salah satunya terkait dengan bencana kekeringan saat ini yang mengancam penurunan produksi pangan nasional. Data Kementerian Pertanian pada bulan Januari-Juli 2011 menunjukkan daerah kekeringan 73,703 ha dan puso 2,089 ha, yang mengalami peningkatan di bulan Agustus 95,851 ha dan puso sebesar 3,713 ha. Dari jumlah itu, urutan pertama adalah Sulawesi Selatan dengan kekeringan 27,889 ha dan puso 1,490 ha (BNPB, 2011).

Kabupaten Sidrap dan Pinrang merupakan daerah yang berada di wilayah sungai Kariango yang termasuk sentra produksi beras di Sulawesi Selatan yang telah mengalami kekeringan. Balai Penyuluh Kecamatan (BPK) Patampanua Kabupaten Pinrang melaporkan bahwa perkembangan intensifikasi tanaman padi musim tanam April-September 2011, menunjukkan 3 desa yang mengalami kekeringan (puso) antara lain: Desa Sipatuo seluas 180 ha, Desa Malimpung seluas 317 ha dan Desa Padang Loang seluas 51 ha.

Saat ini terdapat 3 indeks kekeringan popular yang sering digunakan yaitu Indeks kekeringan Borger untuk kekeringan meteorologi, Indeks suplai air permukaan (Surface Water Supply Index) untuk kekeringan hidrologi, dan Indeks keparahan kekeringan 
Palmer (Palmer Drought Severity Index) untuk kawasan budidaya pertanian. Pada dasarnya dalam penentuan kekeringan didasarkan pada objek kekeringannya, belum terdapat adanya gabungan antara kekeringan satu dan lainnya. Wilayah sungai Kariango pada bulan kering mengalami kekurangan air baik untuk masyarakat maupun untuk pertanian. Penelitian ini mencoba merumuskan indeks kekeringan yang dapat menjawab kekeringan hidrologis dan pertanian di lokasi penelitian. Effendy (2011) menyatakan diperlukan indeks kekeringan baru dengan memasukkan parameter unsur meteorologi (curah hujan, suhu udara, evaporasi, kelembaban nisbi udara) dan unsur lain berupa sumber air, tanah, vegetasi dan populasi.

BNPB (2011) telah memetakan indeks risiko kekeringan di Sulawesi selatan dengan skala 1:1,700,000, dan wilayah sungai Kariango berada dalam kelas sedang. Pemetaan tersebut memiliki cakupan besar dan belum dapat dipakai untuk penanggulangan kekeringan di daerah yang detil. Perumusan upaya mitigasi memerlukan analisis bahaya kekeringan dengan skala detil di lokasi tersebut karena wilayah sungai Kariango termasuk sentra produksi beras di Sulawesi Selatan.

Penelitian ini baru, dengan tujuan membuat indeks dan peta bahaya kekeringan agro-hidrologi serta mengetahui sebaran bahaya kekeringan pada penggunaan lahan di wilayah sungai Kariango.

\section{BAHAN DAN METODE}

\section{Lokasi Penelitian}

Penelitian dilaksanakan di wilayah sungai Kariango Sulawesi Selatan terletak pada $3^{0} 39^{\prime} 0^{\prime \prime}-4^{0} 03^{\prime} 0^{\prime \prime}$ LS dan $119^{0} 34^{\prime} 0^{\prime}$ BT-119 $53^{0} 0^{\prime}$ "BT tersaji pada Gambar 1 dengan luas secara administrasi terletak dalam 3 Kabupaten di Sulawesi Selatan yaitu Kabupaten Pinrang, Sidrap, dan Enrekang seluas 80,365 ha.

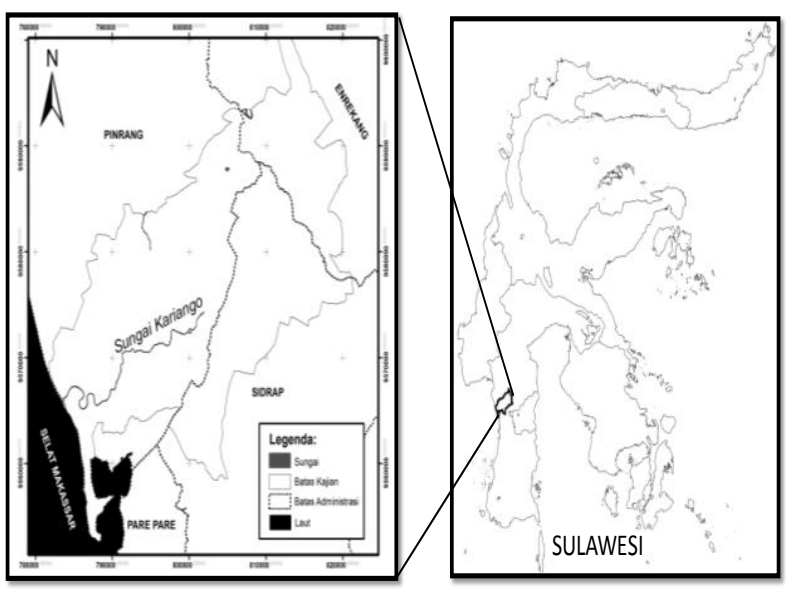

Gambar 1. Lokasi penelitian

\section{Bahan dan Alat}

Bahan yang digunakan meliputi literatur yang berkaitan dengan lokasi dan kajian berupa peta tematik, citra satelit, kuesioner serta bahan lain yang menunjang penelitian, sedangkan alat yang digunakan berupa seperangkat komputer dengan perangkat lunak GIS, perangkat lunak inderaja, Microsoft Office Word dan
Excel, Global Positioning System (GPS) dan alat tulis menulis.

\section{Jenis dan Sumber Data}

Data primer berupa data citra Landsat dan data yang diperoleh melalui survei dan wawancara penduduk dengan menggunakan kuesioner, sedangkan data sekunder terdiri dari data spasial dan data tabular antara lain batas administrasi BPDAS Saddang Sulsel, data wilayah sungai Kariango dan curah hujan BMKG Maris, Sulsel; peta tanah skala 1:250,000 (PPT Bogor); citra Landsat ETM7 2011; sungai (peta RBI 1:50,000), kedalaman sumur (survei dan wawancara); dan validasi data kekeringan (survei dan wawancara).

Penelitian dilakukan dalam 3 tahap, yaitu 1) pengumpulan data, 2) pengolahan data awal, dan 3) analisis data yang diagramatiknya disajikan pada Gambar 2.

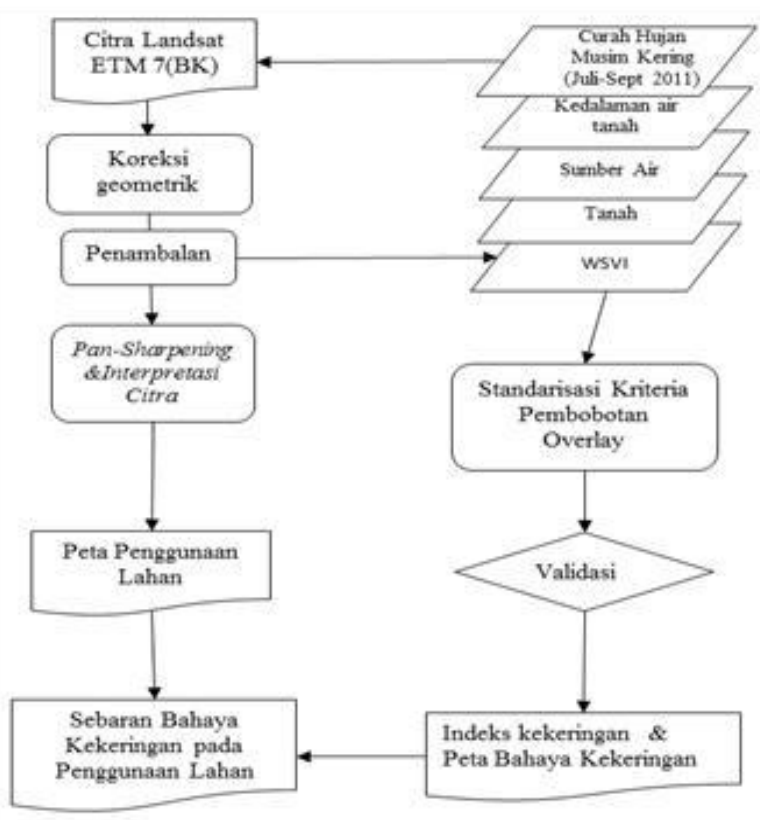

Gambar 2. Diagram alir penelitian

\section{Metode Analisis}

\section{Pengolahan Data Awal}

Langkah pertama adalah menentukan daerah penelitian dengan melakukan clip antara batas administrasi dan batas DAS Kariango. Pemilihan citra Landsat yang digunakan dalam analisis berdasarkan perekaman pada hasil analisis data curah hujan musim kering (JuliSeptember 2011) di mana terdapat bulan kering yang sangat ekstrim dan kemudian dilakukan koreksi geometrik. Citra Landsat ETM 7 tahun 2003 sampai sekarang mengalami striping sehingga diperlukan penambalan. Penambalan diperlukan untuk mengisi nilai pada citra yang striping yang sangat penting dalam ekstraksi data citra. Citra yang digunakan akuisisi musim kering (JuliSeptember) yaitu akuisisi 21 September 2011 sebagai citra utama yang ditambal dan akuisisi 3 Juli dan 5 September 2011 sebagai citra pengisi atau penambal citra utama. 
Peta penggunaan lahan diperoleh dari hasil interpretasi citra Landsat. Pada citra Landsat dilakukan penajaman dari cell size $30 \times 30$ band 321, 543, 432 menjadi resolusi $15 \times 15$ dengan melakukan analisis pansharpening band 8. Pansharpening adalah dengan menggabungkan data citra multispectral yang mempunyai resolusi rendah dengan citra pankromatik yang mempunyai resolusi tinggi (Sitanggang, 2008).

\section{Indeks Bahaya Kekeringan}

Konsep perumusan model indeks kekeringan penelitian adalah adanya suatu nilai yang menggambarkan karakteristik kekeringan agro-hidrologi. Pembuatan indeks ini mengacu pada Effendy (2011) dengan memasukkan parameter unsur meteorologi dan unsur lain berupa sumber air, tanah, vegetasi dan populasi. Konsep yang dikembangkan peneliti untuk nilai indeks kekeringan yaitu gabungan dari beberapa variabel, sebagai berikut:

\section{Water Supplying Vegetation Index (WSVI)}

Indeks Ketersediaan Air Tanaman (Water Supplying Vegetation Index, WSVI) adalah metode untuk mendeteksi informasi kekeringan dengan menggunakan data satelit meteorologi. WSVI dapat menggambarkan kekeringan pertanian, ketika vegetasi mengalami kekeringan NDVI menurun dan suhu kanopi meningkat sehingga nilai WSVI menurun yang menunjukan gambaran kekeringan. Citra yang digunakan adalah citra Landsat ETM7 karena citra Landsat memenuhi persyaratan dengan adanya band 6 (Thermal). Metode ini didasarkan pada kenyataan bahwa vegetasi yang tumbuh situasi tergantung erat pada kondisi ketersediaan air, yang dihitung dengan rumus (Zhao et al., 2005 dalam Sivakumar et al., 2005) sebagai berikut :

$W S V I=N D V I / T_{s}$

dimana: NDVI adalah indeks kehijauan vegetasi dan $\mathrm{T}_{\mathrm{s}}$ adalah temperatur permukaan saluran 6 citra Landsat.

Nilai NDVI diperoleh dari analisis citra Landsat dengan perhitungan indeks kehijauan vegetasi (NDVI) didasarkan pada persamaan matematis sebagai berikut:

$\mathrm{NDVI}=\frac{(\mathrm{NIR}-\mathrm{VR})}{(\mathrm{NIR}+\mathrm{VR})}$

dimana:

NDVI = Indeks kehijauan vegetasi (Normalized Difference Vegetation Index)

NIR = Infra merah dekat (Near InfraRed)

$\mathrm{VR}=$ Band merah (Visible Red)

Sedangkan Nilai $\mathrm{T}_{\mathrm{s}}$ (temperatur permukaan) dihitung berdasarkan hasil analisis citra Landsat 7 saluran 6 (Infra merah thermal dengan panjang gelombang 10.4$12.5 \mu \mathrm{m})$. Tahapan dalam penentuan temperatur permukaan lahan adalah sebagai berikut:

1. Menentukan nilai radiansi spektral objek yang terdapat pada citra dari nilai dijital pikselnya dengan menggunakan persamaan USGS (2003):

$L_{\lambda}=L_{\min \lambda}+\frac{L_{\max \lambda}-L_{\min \lambda}}{Q_{\text {calmax }}} x Q_{c a l}$ dimana :

$\mathrm{L}_{\lambda} \quad=$ radiansi spektral yang diterima sensor untuk piksel yang dianalisis,

$\mathrm{L}_{\min (\lambda)}=$ radiansi spektral minimum yang terdapat pada scene $\left(0.1238 \mathrm{~m} \mathrm{~W} \mathrm{~cm}^{-2} \mathrm{sr}^{-1} \eta^{-1} \mathrm{~m}^{-1}\right)$

$\mathrm{L}_{\text {maks }} \quad=$ radiansi spektral maksimum yang terdapat pada scene $\left(1.56 \mathrm{~m} \mathrm{~W} \mathrm{~cm}^{-2} \mathrm{sr}^{-1} \eta^{-1} \mathrm{~m}^{-1}\right)$

$\mathrm{Q}_{\mathrm{cal}} \quad=$ nilai piksel yang dianalisis

$\mathrm{Q}_{\text {calmaks }}=$ nilai piksel maksimum $($ nilainya $=255)$

2. Menentukan temperatur radian berdasarkan nilai radiansi spektral dengan menggunakan persamaan USGS (2003) :

$\left.\mathrm{T}_{b}=\frac{\mathrm{K}_{2}}{\operatorname{In} \mathrm{K}_{1} / \mathrm{L}_{\lambda}+1}\right)$

dimana:

$\mathrm{T}_{\mathrm{R}} \quad=$ temperatur radian $\left({ }^{0} \mathrm{~K}\right)$ untuk setiap piksel yang dianalisis

$\mathrm{K}_{1} \quad=$ konstanta kalibrasi $\left(666.09 \mathrm{~m} \mathrm{~W} \mathrm{~cm}^{-2} \mathrm{sr}^{-1} \mathrm{\eta} \mathrm{m}^{-1}\right)$

$\mathrm{K}_{2} \quad=$ konstanta kalibrasi $(1260.56 \mathrm{~K})$

$\mathrm{L}_{\lambda} \quad=$ radiansi spektral

3. Menentukan temperatur kinetik berdasarkan temperatur radian dengan menggunakan persamaan (Weng, 2001):

$$
\mathrm{T}_{s}=\frac{\mathrm{T}_{s}}{1+\lambda \mathrm{T}_{\mathrm{s}} / \alpha \operatorname{In} \varepsilon}
$$

dimana :

$\mathrm{T}_{\mathrm{s}} \quad=$ Suhu permukaan yang terkoreksi $(\mathrm{K})$

$\lambda=$ Panjang gelombang dari radiasi yang pancarkan sebesar $11.5 \mu \mathrm{m}$

$=\mathrm{hc} / \mathrm{K}\left(1,438 \times 10^{-2} \mathrm{mK}\right)$

h $\quad=$ Konstanta Planck's $\left(6.26 \times 10^{-3}\right)$

c $\quad=$ Kecepatan cahaya $\left(2,998 \times 10^{8} \mathrm{~m}, \mathrm{scc}^{-\mathrm{I}}\right)$

$\mathrm{K}=$ Konstanta Stefan Boltzman $\left(1.38 \times 10^{-23} \mathrm{JK}^{-1}\right)$

$\varepsilon \quad=$ Emisivitas objek (non-vegetasi 0.96 dan vegetasi 0.97, dan air 0.92 (Weng, 2001)

Indeks ini belum terdapat pengkelasan yang baku sehingga dalam pengkelasannya dalam penelitian ini dilakukan berdasarkan perubahan kelompok data secara alami (natural break).

\section{Curah Hujan}

Peta curah hujan diperoleh dari data curah hujan musim kering (Juli-September, 2011) pada 7 stasiun hujan, yang diinterpolasi. Dalam pengelompokan curah hujan dilakukan berdasarkan metode Schmidt-Ferguson, dimana jumlah hujan $<60 \mathrm{~mm}^{\text {bulan }}{ }^{-1}$ berarti kering. Jumlah hujan $<60 \mathrm{~mm}$ tersebut merupakan batasan pengelompokan peta curah hujan yang dibagi menjadi 5 kelas.

\section{Kedalaman Air Tanah}

Kedalaman air tanah menggambarkan ketersediaan air pada lapisan tanah atau batuan di bawah permukaan tanah. Data kedalaman air tanah diperoleh dari hasil wawancara masyarakat mengenai kedalaman air pada lapisan tanah relatif dekat dari permukaan tanah (sumur galian) maupun lapisan air tanah yang jauh dari permukaan tanah (sumur bor) yang dipetakan dengan interpolasi kriging. 


\section{Jaringan Sungai}

Peta jaringan sungai diperoleh dari data sungai yang diturunkan dari peta jaringan sungai/tubuh air peta RBI skala 1:50,000. Secara umum ditemukan bahwa pada sawah dan pemukiman yang berjarak 100 meter dari sungai merupakan zona aman dari kesulitan air. Sempadan 100 meter merupakan batasan dalam pengkelasan peta sumber air.

\section{Tanah}

Peta tekstur tanah diperoleh dari peta tanah berdasarkan karakteristik jenis tanah yang diperoleh dari Peta Jenis Tanah Skala 1:250,000. Pengkelasan berdasarkan kapasitas ketersediaan air (USDA Natural Resources Conservation Service, 2008) menjadi 5 kelas. Data tekstur diperbaiki diverifikasi terbatas di lapangan.

Selanjutnya, kelas parameter penentuan indeks dan skor yang telah distandarisasi disajikan pada Tabel 1.

Tabel 1. Skor parameter indeks bahaya kekeringan di lokasi penelitian

\begin{tabular}{|c|c|c|}
\hline Parameter & Kelas & Skor \\
\hline Curah Hujan Musim & a. $>60$ & 1 \\
\hline Kering & b. $45-60$ & 2 \\
\hline \multirow[t]{3}{*}{$\left(\mathrm{mm} \mathrm{bln}{ }^{-1}\right)$} & c. $30-45$ & 3 \\
\hline & d. $15-30$ & 4 \\
\hline & e. $<15$ & 5 \\
\hline \multirow{5}{*}{$\begin{array}{l}\text { Sumber Air Permukaan } \\
\text { (Sungai dan Irigasi) }\end{array}$} & a. $0-100 \mathrm{~m}$ & 1 \\
\hline & b. $100-200 \mathrm{~m}$ & 2 \\
\hline & c. $200-300 \mathrm{~m}$ & 3 \\
\hline & d. $300-400 \mathrm{~m}$ & 4 \\
\hline & e. $>500 \mathrm{~m}$ & 5 \\
\hline \multirow[t]{5}{*}{ Tekstur } & a. Lempung berdebu & 1 \\
\hline & b. Lempung berliat & 2 \\
\hline & c. Liat, Liat berpasir & 3 \\
\hline & d. Lempung berpasir & 4 \\
\hline & e. Pasir Berlempung & 5 \\
\hline \multirow{5}{*}{$\begin{array}{l}\text { Kedalaman air Tanah } \\
\text { (sumur) }\end{array}$} & a. $4.00-11.4 \mathrm{~m}$ & 1 \\
\hline & b. $11.4-17.9 \mathrm{~m}$ & 2 \\
\hline & c. $17.9-24.1 \mathrm{~m}$ & 3 \\
\hline & d. $24.1-33.5 \mathrm{~m}$ & 4 \\
\hline & e. $33.0-50.0 \mathrm{~m}$ & 5 \\
\hline \multirow{5}{*}{$\begin{array}{l}\text { Vegetasi } \\
\text { (Water Supplying } \\
\text { Vegetation Index) }\end{array}$} & a. $-0.0564-(-) 0.0103$ & 5 \\
\hline & b. $-0.0103-(-) 0.0009$ & 4 \\
\hline & c. $-0.0009-0.0092$ & 3 \\
\hline & d. $0.0092-0.0189$ & 2 \\
\hline & e. $0.0189-0.0563$ & 1 \\
\hline
\end{tabular}

\section{Pembobotan Faktor Indeks Bahaya Kekeringan}

Semua parameter yang telah distandarisasi dengan skor 1-5, selanjutnya diberikan pembobotan berdasarkan pengaruhnya dengan menggunakan metode perankingan dengan rumus sebagai berikut:

$w_{j}=\frac{\mathrm{n}-\mathrm{rj}+1}{n-r j+1} .$.

dimana:

$\mathrm{W}_{\mathrm{j}} \quad=$ Nilai bobot yang dinormalkan

$\mathrm{n} \quad=$ Jumlah kriteria $(1,2,3, \ldots)$

$\mathrm{r}_{\mathrm{j}} \quad=$ Posisi urutan kriteria

\section{Rumusan dan Implementasi Indeks Bahaya Kekeringan}

Sesuai dengan konsep teori indeks (Spiegel, 1961), perumusan indeks dimulai dari paling sederhana, yaitu penambahan variabel yang disesuaikan dengan tujuan karakteristik indeks yang akan dicapai. Perumusan indeks kekeringan dilakukan dengan penggabungan dari beberapa parameter indeks dan pengaruhnya yang kemudian dikelaskan. Rumusan Indeks Kekeringan AgroHidrologi yang dibuat adalah sebagai berikut :

$$
\begin{aligned}
& \mathrm{Ibk}=\mathrm{c} 1 \mathrm{CH}+\mathrm{c} 2 \mathrm{KAT}+\mathrm{c} 3 \mathrm{SA}+\mathrm{c} 4 \mathrm{~T}+ \\
& \text { c5WSVI .............................. (7) } \\
& \text { dimana: } \\
& \text { Ibk = Indeks Bahaya Kekeringan } \\
& \mathrm{CH}=\text { Skor curah hujan } \\
& \text { KAT = Skor kedalaman air tanah } \\
& \text { SA }=\text { Skor sumber air } \\
& \mathrm{T}=\text { Skor tekstur tanah } \\
& \text { WSVI = Skor Indeks ketersediaan air tanaman (Water } \\
& \text { Supplying Vegetation Index) } \\
& \text { c1- c5 = Nilai bobot masing-masing faktor }
\end{aligned}
$$

Hasil yang diperoleh dari analisis Indeks Bahaya Kekeringan Agro-Hidrologi ini menghasilkan peta Bahaya Kekeringan Agro-Hidrologi yang berskala tertentu. Penentuan skala peta berdasarkan rumus Tobler (1987) dalam ESRI (2010).

Skala $=$ Resolusi $\times 2 \times 1000$

\section{Validasi Lapangan}

Validasi lapangan dilakukan untuk membandingkan hasil analisis Indeks Bahaya Kekeringan Agro-Hidrologi yang dirumuskan dengan keadaan sebenarnya di lapangan. Data validasi berupa: 1) titik-titik kekeringan yang diperoleh dari hasil wawancara petani, masyarakat dan pemerintah, dan 2) korelasi luasan data puso dengan luasan model kekeringan yang diperoleh dari Badan Penyuluh Kecamatan.

\section{HASIL DAN PEMBAHASAN}

Kondisi geobiofisik wilayah mempengaruhi penggunaan lahan. Peta penggunaan lahan daerah sungai Kariango diperoleh dari berdasarkan hasil interpretasi citra Landsat 7 ETM dengan digitasi on-screen. Sebelum dilakukan interpretasi citra Landsat striping dilakukan gap fill (penambalan) selain untuk memperjelas dalam mendeliniasi juga mengisi nilai pada citra terkhusus band 6 dalam analisis WSVI.

Tahapan berikutnya dilakukan penajaman citra menjadi cell size $15 \times 15$ hasil pansharpening dan dilakukan deliniasi penggunaan lahan DAS Kariango dengan bantuan peta penggunaan lahan Dinas Kehutanan tahun 2010. Jenis penggunaan lahan hasil digitasi onscreen yaitu hutan, tubuh air, tambak, kebun campuran, pertanian lahan kering/tegalan, mangrove, semak/belukar, pemukiman dan sawah (Gambar 3 dan Tabel 2). Penggunaan lahan yang terluas adalah sawah seluas 40,185 ha atau $50 \%$ dari luasan penggunaan lahan. 


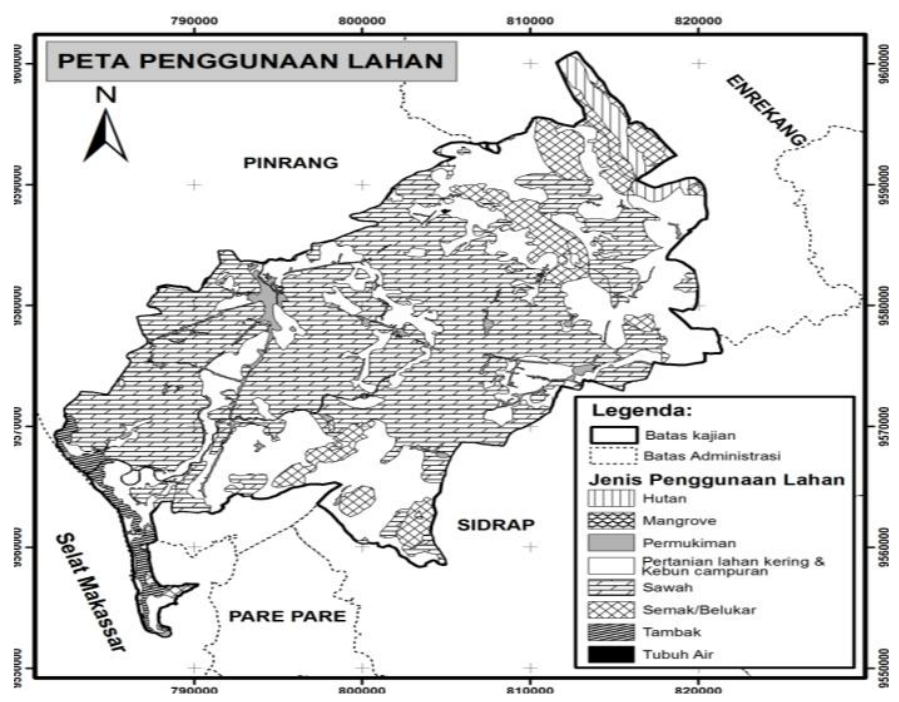

Gambar 3. Peta penggunaan lahan wilayah sungai Kariango

Tabel 2. Jenis penggunaan lahan 2011 hasil dijitasi on-screen

\begin{tabular}{lcc}
\hline \multirow{2}{*}{ Jenis Penggunaan Lahan } & \multicolumn{2}{c}{ Luas } \\
\cline { 2 - 3 } & ha & \% \\
\hline Hutan & 1,595 & 1.98 \\
Tubuh Air & 216 & 0.27 \\
Tambak & 1,328 & 1.65 \\
Pertanian lahan kering/kebun & 27,831 & 34.6 \\
campuran & 42.7 & 0.05 \\
Mangrove & 7,148 & 8.89 \\
Semak/Belukar & 2,018 & 2.51 \\
Permukiman & 40,185 & 50.0 \\
Sawah & $\mathbf{8 0 , 3 6 5}$ & $\mathbf{1 0 0 . 0 0}$ \\
\hline Jumlah &
\end{tabular}

\section{Indeks Kekeringan Agro-Hidrologi}

Kekeringan agro-hidrologi dapat diartikan kurangnya pasokan air permukaan dan air tanah sehingga tidak mampu memenuhi/mempengaruhi kebutuhan tanaman dan masyarakat pada periode waktu tertentu. Dalam kajian indeks bahaya kekeringan agro-hidrologi, pemilihan faktor yang digunakan dan bobot kepentingan didasarkan pada konsep air tersedia.

Intensitas hujan yang rendah pada musim kemarau sangat mempengaruhi terjadinya kekeringan, setiap penyimpangan curah hujan secara langsung akan mempengaruhi tingkat kedalaman air tanah (Dileep et al., 2007). Jika muka air tanah cukup dalam, maka kapasitas akuifernya relatif kecil, sehingga daerah tersebut akan mudah mengalami kekeringan, demikian pula sebaliknya. Kedalaman air tanah mencerminkan kapasitas akuifer untuk menyimpan air dan mengalirkan ke sungai. Sungai mempunyai peranan yang sangat penting dalam fungsinya sebagai tempat mengalirkan air. Semakin dekat dengan sumber air maka daerah tersebut kecil kemungkinan mengalami kejadian kekeringan. Air permukaan tanah dan air tanah yang mengalir ke sungai berhubungan langsung dengan tekstur tanah dalam pola gerakan air (Indarto, 2010). Tekstur tanah dapat meningkatkan atau mengurangi efek kekeringan, karena perbedaan dalam aerasi memegang air (Berger et al., 2012). Tekstur tanah menentukan jumlah air yang dapat diikat pada berbagai kondisi kadar lengas tanah; semakin baik daya ikat air tanah akan semakin baik untuk kebutuhan dan ketersediaan air bagi masyarakat dan tanaman (air tanah dipompa oleh perakaran tanaman). Jenis tanaman, kerapatan penutupan dan penutupan tanaman berpengaruh langsung terhadap jumlah air pada permuakan tanah di dalam DAS (Indarto, 2010). Ketika vegetasi mengalami kekeringan, NDVI menurun dan suhu kanopi meningkat, WSVI menurun. Oleh karena itu, WSVI dapat mencerminkan kekeringan efektif (Zhao et al., 2005 dalam Sivakumar et al., 2005).

Dalam penentuan tingkat bahaya kekeringan dilakukan pembobotan semua parameter berdasarkan urutan kepentingannya, yaitu semakin besar pengaruhnya maka bobot yang diberikan juga semakin besar. Konsep pemilihan penentuan faktor parameter dan urutan pengaruhnya dalam rumusan indeks bahaya kekeringan sebagai berikut: kurangnya curah hujan menjadi indikator awal suatu wilayah rawan kekeringan sehingga parameter ini diputuskan menempati bobot pertama. Air tanah secara langsung berpengaruh bila curah hujan kurang yang sifatnya menampung air hujan dan mengalirkannya ke sungai, sehingga bobot air tanah lebih tinggi dari bobot sungai. Semakin dalam air tanah dan jauh dari sumber air menggambarkan rawan kekeringan. Tekstur tanah mengurangi dan meningkatkan efek kekeringan karena perbedaan dalam daya mengikat air dan menyalurkannya. Selanjutnya vegetasi tergantung pada tekstur tanah memenuhi kebutuhan tanaman.

Berdasarkan dari ulasan tersebut, maka parameter yang terpilih diurut berdasarkan kepentingan dan bobotnya sehingga diperoleh bobot normalisasi dengan menggunakan metode rasional. Pembobotan parameter yang mempengaruhi kekeringan disajikan pada Tabel 3.

Tabel 3. Bobot normalisasi parameter

\begin{tabular}{lccc}
\hline \multicolumn{1}{c}{ Parameter } & $\begin{array}{c}\text { Urutan } \\
\text { Kepentingan }\end{array}$ & $\begin{array}{c}\text { Urutan } \\
\text { Bobot }\end{array}$ & $\begin{array}{c}\text { Bobot } \\
\text { Normalisasi }\end{array}$ \\
\hline Curah Hujan (CH) & 1 & 5 & 0.33 \\
Kedalaman Air & 2 & 4 & 0.27 \\
Tanah (KAT) & 3 & 3 & 0.20 \\
Sumber air (SA) & 4 & 2 & 0.13 \\
Tekstur Tanah (T) & & 1 & \\
$\begin{array}{l}\text { Water Supplying } \\
\text { Vegetation Index } \\
\text { (WSVI) }\end{array}$ & 5 & & 0.07 \\
\hline
\end{tabular}


Dari hasil pembobotan yang dibuat dihasilkan persamaan yang digunakan dalam persamaan Indeks Bahaya Kekeringan Agro-hidrologi sebagai berikut :

$$
\mathrm{Ibk}=\begin{aligned}
0.33 \mathrm{CH}+0.27 \mathrm{KAT}+(0.20 \mathrm{SA}+0.13 \mathrm{~T}+ \\
(0.06 \mathrm{WSVI}) \ldots \ldots \ldots \ldots \ldots \ldots \ldots \ldots \ldots \ldots \ldots \ldots \ldots \ldots \ldots \ldots \ldots \ldots \ldots \ldots \ldots \ldots
\end{aligned}
$$

dimana :

Ibk = Indeks Bahaya Kekeringan

$\mathrm{CH}=$ Skor curah hujan

KAT $=$ Skor kedalaman air tanah

SA $\quad=$ Skor sumber air

$\mathrm{T}=$ Skor tekstur tanah

WSVI = Skor Indeks ketersediaan air tanaman (Water

Supplying Vegetation Index)

Penentuan nilai kelas bahaya, skor dari kelima parameter yang dikalikan dengan bobot normalisasi dibagi dalam beberapa kelas yaitu aman, rendah, sedang dan tinggi.

Pembuatan peta bahaya kekeringan dilakukan dengan cara menjumlahkan nilai skor keseluruhan dari hasil tumpang tindih peta tematik penyebab kekeringan yang disusun. Semua parameter yang digunakan telah distandarisasi dengan ukuran piksel yang sama $30 \times 30 \mathrm{~m}^{2}$ mengikuti ukuran piksel citra Landsat sehingga skala peta yang dihasilkan dari analisis indeks bahaya kekeringan agro-hidrologi tersebut menghasilkan skala peta 60,000.

Validasi model kekeringan yang dibuat dengan kekeringan aktual di lokasi penelitian sangat akurat dari tolak ukur titik validasi lapangan 96\%, dimana dari 53 titik validasi lapangan yang diperoleh dari hasil wawancara kelompok tani dan masyarakat terdapat 51 titik yang sesuai dan yang tidak sesuai (error). Ada 2 titik yaitu titik yang mengalami kekeringan dan tidak kering. Sebaran kekeringan di DAS Kariango disajikan pada Gambar 4.

Gambar 5 menunjukkan korelasi yang sedang antara luasan puso dan luasan model yang mengalami kekeringan. Sejauh ini belum ada standarisasi yang dapat digunakan acuan untuk mengukur keakuratan tingkat kekeringan di lapangan dan tingkat kekeringan di model kekeringan. Hal ini dikarenakan belum ada persepsi petani dan pemerintah yang sama mengenai tingkat kekeringan di lapangan dan bencana kekeringan tidak seperti bencana lain seperti longsor dan banjir yang meninggalkan jejak tingkat bencana.

Terkait dengan data puso tidak bisa digunakan dalam membandingkan tingkat kekeringan karena klasifikasi puso sendiri juga belum ada persepsi yang sama antara petani dan pemerintah. Selain itu, dari informasi petani yang diwawancarai, banyak lahan sawah mereka yang mengalami gagal panen tidak ikut terdata dalam kategori puso dan yang terdata hanya sebagian petani yang tergabung dalam kelompok tani.

Analisis tumpang tindih yang dilakukan menghasilkan wilayah-wilayah yang menggambarkan kondisi kekeringan di wilayah tersebut. Wilayah bahaya kekeringan dapat diartikan sebagai daerah terancam kekeringan cukup tinggi karena curah hujan rendah dan sumber air tanah terbatas, atau daerah yang mempunyai faktor fisik lahan/tanah yang dapat mempercepat timbulnya kekeringan. Nilai bahaya kekeringan (Tabel 4) menunjukkan dari total luasan kajian kekeringan hanya terdapat $25.7 \%$ atau seluas 20,618 ha tidak mengalami kekeringan yang berada tidak jauh dari jarak sumber air. Hal ini menunjukkan lokasi kajian sangat rawan bencana kekeringan. Luasan hasil analisis bahaya tidak sesuai dengan luasan wilayah kajian, akibat adanya konversi data raster ke vektor sehingga luasan bertambah sebesar 91.3 ha.

Tabel 4. Kelas bahaya kekeringan beserta luasannya di lokasi penelitian

\begin{tabular}{lccc}
\hline \multirow{2}{*}{ Nilai Interval } & Kelas & \multicolumn{2}{c}{ Luas } \\
\cline { 3 - 4 } & Bahaya & Ha & \% \\
\hline $1.12-2.07$ & Aman & 20,618 & 25.7 \\
$2.07-2.54$ & Rendah & 26,195 & 32.6 \\
$2.54-3.01$ & Sedang & 23,763 & 29.5 \\
$3.01-4.01$ & Tinggi & 9,826 & 12.2 \\
\hline Jumlah & & $\mathbf{8 0 , 4 5 6 . 6 4}$ & $\mathbf{1 0 0 . 0 0}$ \\
\hline
\end{tabular}

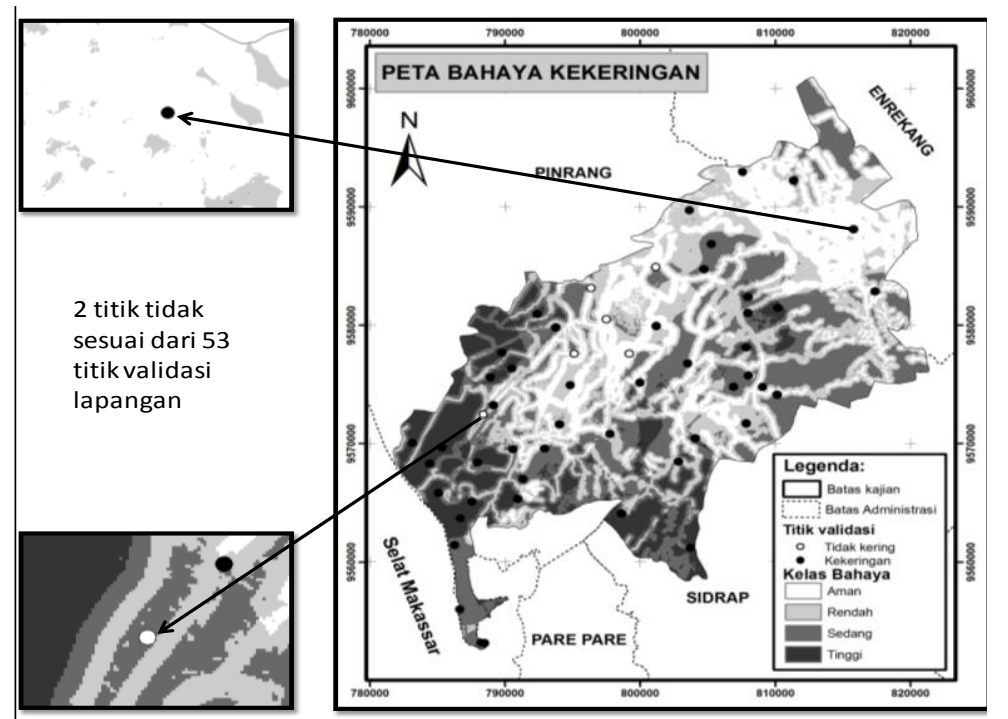

Gambar 4. Peta bahaya kekeringan dan validasi titik lapangan 

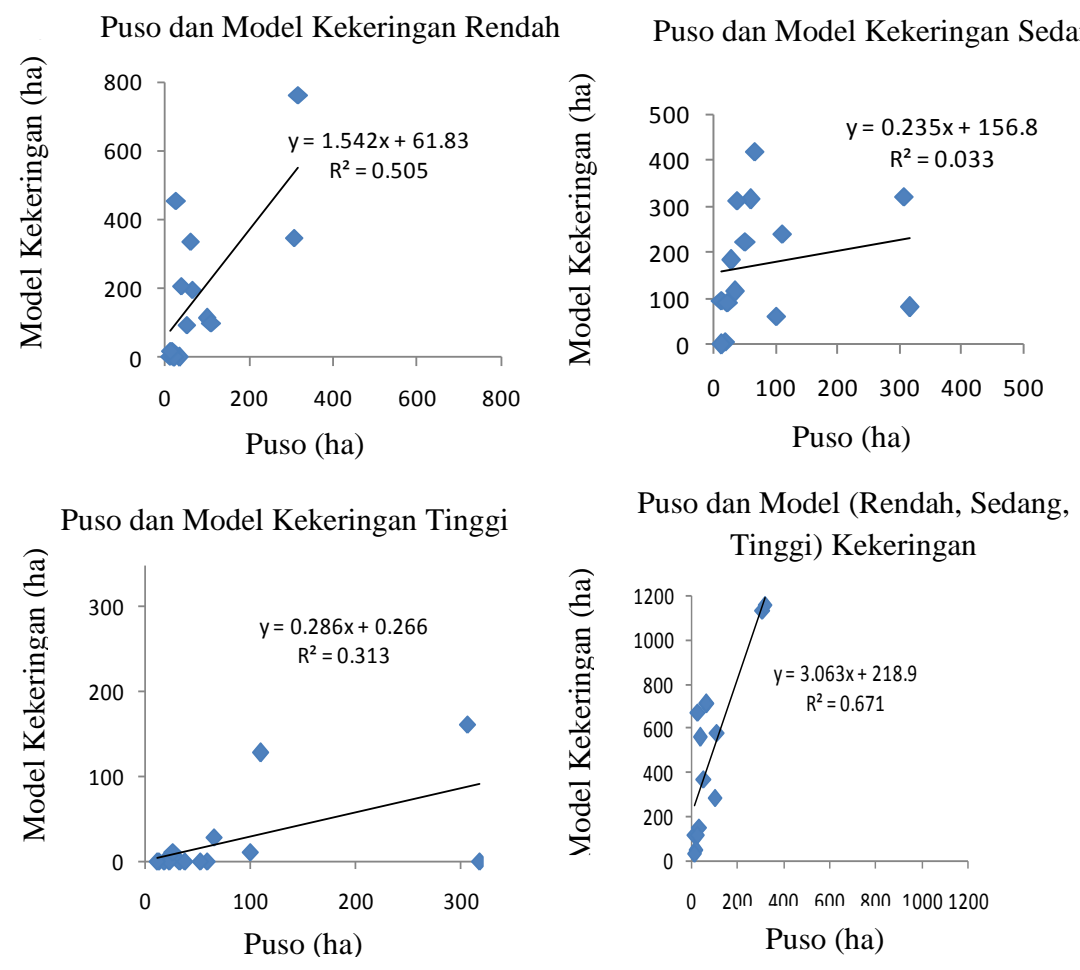

Gambar 5. Korelasi luasan data puso dan luasan model kekeringan

\section{Sebaran Bahaya Kekeringan}

Indeks dan peta bahaya yang dirumuskan sangat akurat dengan validasi titik kekeringan di lapangan. Indeks bahaya kekeringan ini dapat menjadi indikator bencana kekeringan. Pemanfaatan indikator tertentu sering dilakukan dalam penilaian status atau suatu fenomena atau ukuran-ukuran kuantitatif ataupun kualitatif (Barus et al., 2010). Wilayah Sungai Kariango tergolong kritis dengan luasan hutan hanya seluas $1.98 \%$. Dari indikasi ini maka wajar wilayah sungai Kariango sering mengalami kekeringan karena sedikitnya hutan yang berfungsi sebagi daerah tangkapan air. Sebaran bahaya kekeringan pada penggunaan lahan lokasi kajian disajikan pada Gambar 6. Hasil pengkelasan tingkat kekeringan dapat memberikan indikasi bahwa sebaran penggunaan lahan sawah, pertanian lahan kering dan kebun campuran sangat terancam bahaya kekeringan.

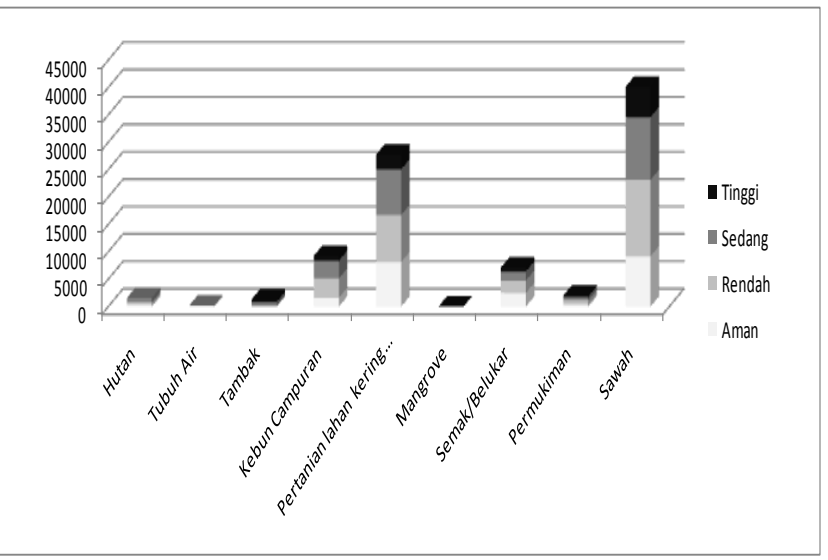

Gambar 6. Sebaran bahaya kekeringan pada penggunaan lahan wilayah Sungai Kariango

\section{SIMPULAN}

Berdasarkan hasil penelitian ini maka disusun Indeks Bahaya Kekeringan Agro-Hidrologi di lokasi kajian sebagai berikut:
Ibk $=(0.33 \mathrm{CH})+(0.27 \mathrm{KAT})+(0.20 \mathrm{SA})+(0.13 \mathrm{~T})+$ (0.06WSVI)

Hasil yang diperoleh dapat menggambarkan kemiripan di lapangan dengan keakuratan $96 \%$ berdasarkan titik validasi. Hasil indeks dan peta bahaya kekeringan dapat digunakan indikator bencana kekeringan yang menggambarkan penggunaan lahan sawah, pertanian lahan kering dan kebun campuran terancam bahaya kekeringan.

\section{DAFTAR PUSTAKA}

Barus, B., U. Sudadi, B. Tjahjono, dan L.S. Iman. 2010. Pemanfaatan geoindikator dalam penataan ruang. Prosiding Seminar Nasional Science III. Fakultas MIPA IPB bekerjasama dengan MIPAnet. Bogor.

[BNPB] Badan Nasional Penanggulangan Bencana. 2011. Kekeringan Picu Krisis Pangan. http://www.bnpb.go.id/website/asp/berita_list.asp . (diakses 29 Januari 2012).

Berger, S., J. Eunyong, K. Julia, K. Hojeong, and G. Gerhard. 2012. Monsoon rains, drought periods and soil texture as drivers of soil $\mathrm{N}_{2} \mathrm{O}$ fluxes. Soil Biol Biochem., 57: 273-281.

Dileep, K. Panda, A. Mishra, S.K. Jena, B.K. James, and A. Kumar. 2007. The influence of drought and 
anthropogenic effects on groundwater levels in Orissa, India. J. Hydrol., 343: 140-153.

Effendy, S. 2011. Geoindikator untuk kekeringan.Workshop Pengembangan Indikator Geo untuk Pengelolaan Risiko Bencana di Indonesia. Tim Pusat Pengkajian Perencanaan dan Pengembangan Wilayah dan LPPM, IPB dengan Kementrian Riset dan Teknologi.

ESRI. 2010. ArcGIS Resources: On map scale and raster resolution. blogs.esri.com/esri/arcgis/2010/12/12/ on-map-scale-and-raster-resolution/. (diakses 8 Januari 2013).

Indarto, 2010. Hidrologi. Dasar Teori dan Contoh Aplikasi Model Hidrologi. PT. Bumi Aksara. Jakarta.

Raharjo, P.D. 2010. Teknik penginderaan jauh dan sistem informasi geografis untuk identifikasi potensi kekeringan. Makara Teknologi, 14:97-105.

Sitanggang, G. 2008. Teknik dan metode fusi (Pansharpening) data ALOS (AVNIR-2 dan PRISM) untuk identifikasi penutup lahan/tanaman pertanian sawah. Majalah Sains dan Teknologi Dirgantara, 3: 33-49.
Spiegel, M.R. 1961. Theory and Problems of Statistics. McGraw-Hill International Book Company. New York.

USDA Natural Resources Conservation Service. 2008. Available Water Capacity. Soil Quality Indicators.

Soils.usda.gov/sqi/assessment/files/available_wat er_capacity_sq_physical_indicator_sheet.pdf.(dia kses 22 Januari 2013).

USGS. 2003. Landsat 7 science data users handbook. http://ltpwww.gsfc.nasa.gov/IAS/ handbook_htmls.(diakses Agustus 2012).

Weng, Q. 2001. A remote sensing - GIS evaluation of urban expansion and its impact on surface temperature in the Zhujiang Delta. Int. J. Remote sensing, 22: 1999-2014.

Zhao, Y., S. Li. and Y. Zhang. 2005. Early Detection and Monitoring of Drought and Flood in hina Using Remote Sensing and GIS. In M.V.K. Sivakumar, R.P. Motha, and Das. P (Eds.). Natural Disasters and Extreme Events in Agriculture. Springer. pp 308-309. 
